\title{
Cerebellar Hemangioblastoma
}

National Cancer Institute

\section{Source}

National Cancer Institute. Cerebellar Hemangioblastoma. NCI Thesaurus. Code C5146.

A histologically benign tumor, usually cystic with a vascular mural nodule, that is most

often found in the cerebellum though it has been reported at other sites within the neuraxis. It is associated with von Hippel-Lindau disease (VHL gene located on chr 3p2526). 